\title{
INVESTIGATING THE EFFECT OF PIPE INLET CUTTING ANGLE ON THE HEAD LOSS OF SYPHON*
}

\author{
Mohamed A. Awad ${ }^{+}$, Gamal M. Abed-Aal, Mohamed N. Salem, Magdy H. Mowafy \\ Water and Water Structures Eng. Dept., Faculty of Eng., Zagazig Univ., Egypt
}

\begin{abstract}
:
This work presents the results of a laboratory study aims to improve the inlet of the pipe syphon to decrease the head losses resulting from the sudden contraction in the pipe. Box-type wing walls are considered upstream and downstream. Theoretical and experimental studies were conducted. For experimental study models with different cutting angles, measured from vertical axis, of pipe inlet $\left(\theta_{1}=0^{\circ}, 15^{\circ}, 30^{\circ}, 45^{\circ}\right.$, and $\left.60^{\circ}\right)$. The pipe syphon was tested under different discharges $(\mathrm{Q}=7.28$ to 57.20 lit./sec). Different downstream submergence ratios $(\mathrm{Hd} / \mathrm{D}=0.0,0.25,0.50,0.75$, and 1.0) were considered. Dimensional analysis is employed to get the relationships between the different factors affecting the head losses through the syphon. The results of the study led to practical recommendations that are useful in the design of syphon inlet with low head losses.
\end{abstract}

KEY WORDS: Pipe entrance, Entrance losses, Cutting angles, Pipe inlet, Syphon losses, and Hydraulics of syphon.

\section{RÉSUMÉ:}

Ce travail présente les résultats d'une étude en laboratoire a pour but d'améliorer l'entrée du siphon de conduite pour diminuer les pertes de charge résultant de la contraction brusque de la conduite. Murs en aile en forme de boîte sont considérés en amont et en aval. Études théoriques et expérimentales ont été menées. Pour les modèles d'études expérimentales avec des angles différents de coupe, mesurés à partir de l'axe vertical, de l'entrée de la conduite $\left(\theta_{1}=0^{\mathrm{O}}, 15^{\mathrm{O}}, 30^{\mathrm{O}}, 45^{\mathrm{O}}\right.$ et $\left.60^{\circ}\right)$. Le siphon de la conduite ont été testés sous différentes décharges $(\mathrm{Q}=$ 7,28 à 57,20 éclairé. / Sec). Ratios de submersion en aval différents ( $\mathrm{HD} / \mathrm{D}=0.0,0.25,0.50,0.75$ et 1.0) ont été concernés. L'analyse dimensionnelle est utilisée pour obtenir les relations entre les différents facteurs qui influent sur les pertes de charge à travers le siphon. Les résultats de l'étude ont conduit à des recommandations pratiques qui sont utiles dans la conception d'entrée de siphon avec de faibles pertes de charge.

MOTS CLÉS: tuyaux d'entrée, les pertes d'entrée, les angles de coupe, entrée de tuyau, pertes Syphon, et hydraulique de siphon.

* Received: $20 / 10 / 2013$, Accepted: 29/12/2013, Ref. No. 166, (Original paper )

+ Contact author $(+201223827244)$. 


\section{INTRODUCTION :}

For the sake of reclamation of new agriculture lands that associated with cut open new canals and drains. Syphon is a very important crossing structure to underpass one stream of low level and small discharges with another. The famous shape of the syphon is the inverted one, otherwise, may be constructed straight between upstream and downstream ends similar to the culvert. The crossed stream levels play an important role to determine the syphon shape and may be named broken-back or sage culvert. The intent is the big resemblance between syphon and culvert in hydraulic performance of each one.

For the matches between straight syphon and culvert, their hydraulic performance are corresponding either, the type of flow through the syphon has a great impact upon the resulting head losses, the flow features of straight syphon or culvert have been understood the advances of Metzler and Rouse [8], Chow (1959) [4], Blasidell [1], Bodhaine [2], Dasika [5], Montes [10], Hager and Giudice [15], and Meselhe, and Hebert [9]. They describe the different types of flow through the culvert and they distinguished between four types of flow take place through the culvert. Critical flow, uniform flow, gated flow, and pressurized flow; all of these types of flow were acquired by many studies as a culvert. There are few studies covering the hydraulic performance of the syphon.

Inlet control is conducted by Magdy $\mathrm{H}$. Mowafy [7], Smith and Oak [12], Robinson [11], Tullis B. and S. Robinson [13]. Recent studies for hydraulic analysis and design of pipe culverts was established, FHWA [14 and 15] and Chin [6]. This study deals with pressurized flow, that distinguished the flow through the syphon, aims mainly to decreasing head losses resulting from cutting angles of the syphon inlet in the pipe syphon.

\section{THEORETICAL STUDY :}

In this section the dimensional analysis is used to correlate the relationships between the different parameters affecting the studied phenomenon. Buckingham's [3] theorem is used for different study cases of the pipe syphon. The use of dimensional analysis is mainly aimed to obtain the relationships for the relative energy losses through the syphon, the effect of submergence ratio, and the relative entrance losses, with respect to the inlet cutting angle.

The various parameters and variables affecting the total head losses through the pipe syphon in classical straight shape is presented in Fig. (1),



Fig. (1) Definition sketch for experimental Model. 
Form Fig. (1) dimensional analysis technique was used and the homogenous function of variable which affect the head loss through the syphon may written in the form as in equation (1),

$$
\frac{E_{t}}{D}=f\left(\theta_{1}, \frac{E_{1}}{D}, \frac{E_{4}}{D}, \frac{H_{e n t}}{D}, \frac{H_{d}}{D}, \frac{H_{u}}{D}, \frac{Q}{\sqrt{D^{5} \cdot g}}\right)
$$

\section{EXPERIMENTAL SETUP :}

The experimental work is carried out in the Hydraulic and Water Engineering Laboratory, Faculty of Engineering, Zagazig University, Egypt. A rectangular circulating flume provided with two flumes is used; the upper flume of $66 \mathrm{~cm}$ width, $65.5 \mathrm{~cm}$ depth, and $16.2 \mathrm{~m}$ long. The lower flume is $100 \mathrm{~cm}$ width, $100 \mathrm{~cm}$ depth, and $18 \mathrm{~m}$ long, a PVC pipe of $19.0 \mathrm{~cm}$ inner diameter, 20.0 $\mathrm{cm}$ outer diameter, and $4.00 \mathrm{~m}$ long is used as a syphon. Clear plastic box type wing walls of 10 $\mathrm{mm}$ thickness are used at the upstream and the downstream ends without any changes during all experiments. The head walls of the syphon are made of steel with $4 \mathrm{~mm}$ thickness. The flume is provided with steel tail gate moved by using manual gear box in order to control downstream water depth. The discharge is measured by a precalibrated rectangular weir of $66.0 \mathrm{~cm}$ width placed at the end of the upper flume to avoid the effect of the structure on the measured head over the weir crest. The discharge through the flume is varied from 7.28 to $57.20 \mathrm{lit} / \mathrm{sec}$ conducted by a pump with controlled steady rate of flow by a valve in order to adjust the discharge for the test.

One hundred and thirty runs are conducted using different downstream submergence ratios of $\left(\mathrm{H}_{\mathrm{d}}\right.$ $/ \mathrm{D}=0.0,0.25,0.50,0.75$, and 1.0 ) are used for the same flow conditions. Different inlet cutting angles $\left(\theta_{1}=0^{\circ}, 15^{\circ}, 30^{\circ}, 45^{\circ}\right.$, and $\left.60^{\circ}\right)$ are considered. The water depths are measured using a manual point gauge carried by a steel carriage moving on rollers.

\subsection{TESTING PROCEDURE :}

Tested model is fixed in the flume, a specified discharge is allowed to pass through the syphon, and the tail gate is adjusted to achieve a particular submerge-ence ratio $\left(H_{d} / D\right)$, until the flow reach steady state case. The measured depth is taken, adjusting tail gate to achieve a new submergence ratio and repeating previous step. After ending different submergence ratios, the discharge passes through the flume is increased to the next value by opening the controlling valve, and repeating all steps again. Photo (1) show the apparatus used in the experimental work.

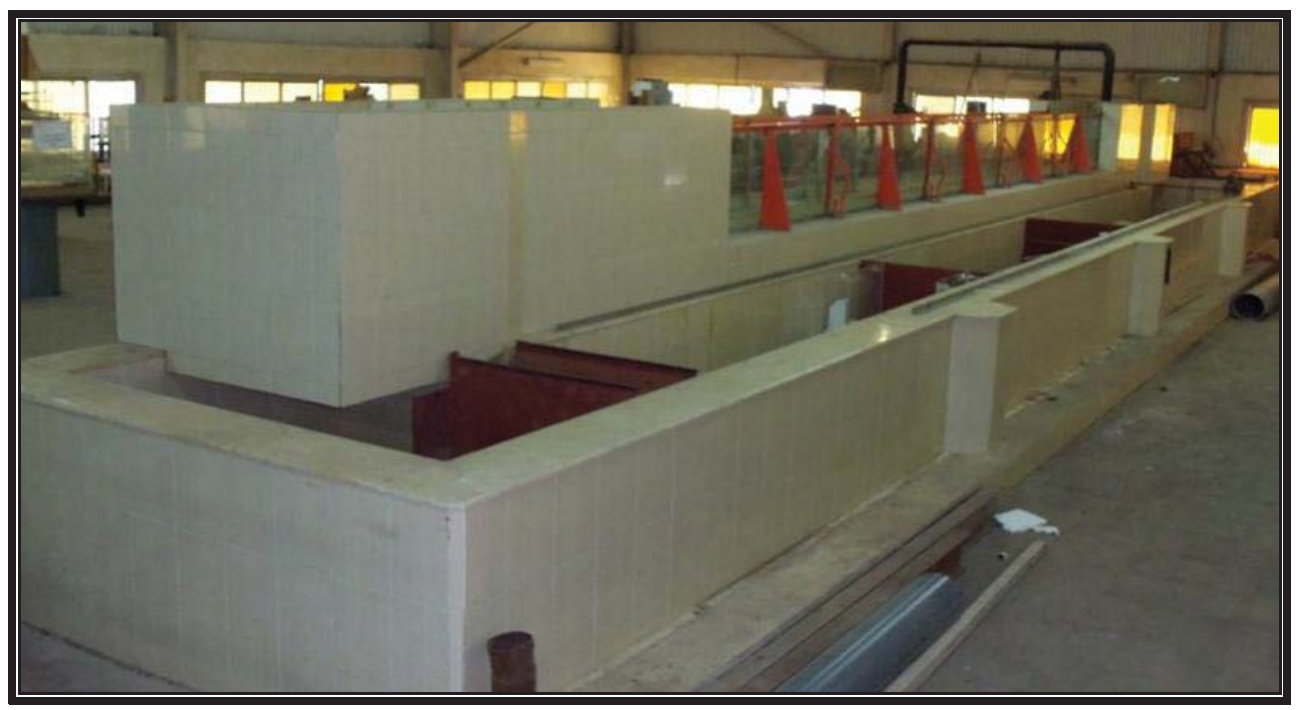

Photo (1) Apparatus used in experimental work. 


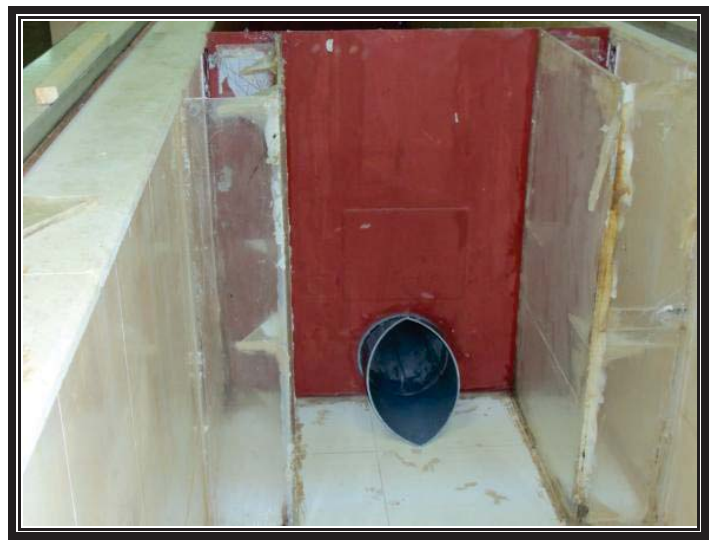

Photo (2) The Inlet of the Syphon.

\section{ANALYSIS AND DISCUSSION :}

The results conducted from the experimental work are analyzed to clarify the effect of the inlet cutting angles on the losses through syphon. Figs. (2) and (3) represents the relationship between $\left(\mathrm{Q} / \sqrt{\mathbf{g} \times \mathbf{D}^{\mathbf{5}}}\right)$ which named as pipe Froude number, and relative upstream energy $\left(E_{1} / D\right)$ for different values of submergence $\left(\mathrm{H}_{\mathrm{d}} / \mathrm{D}\right)$, and for inlet cutting angle ratios $\left(\theta_{1}=0^{\circ}, 15^{\circ}, 30^{\circ}, 45^{\circ}\right.$, and $\left.60^{\circ}\right)$ respectively.

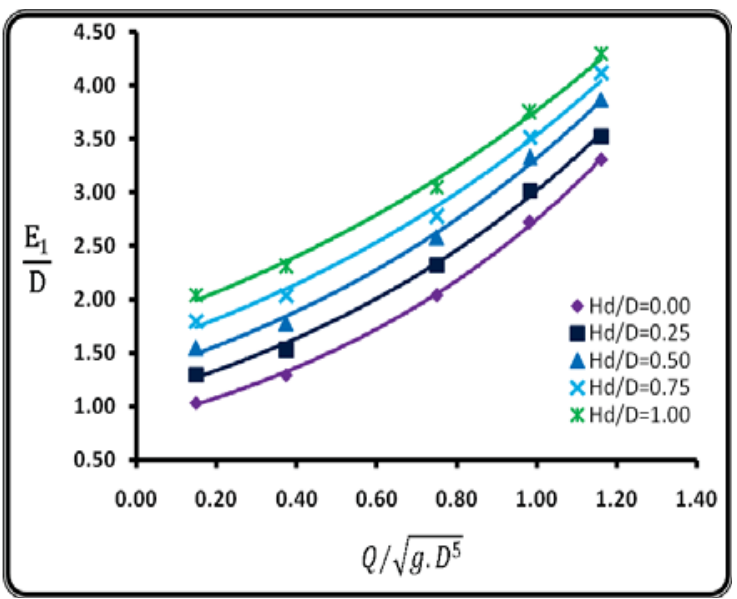

Fig. (2) Relationship between

$\left(\mathrm{Q} / \sqrt{\mathrm{g} \times \mathrm{D}^{5}}\right)$ and $\left(\mathrm{E}_{1} / \mathrm{D}\right)$ for different values of Submerged ratios of $\left(\mathrm{H}_{\mathrm{d}} / \mathrm{D}\right),\left(\theta_{1}=0\right)$.



Photo (3) The Outlet of the Syphon.



Fig. (3) Relationship between

$\left(\mathrm{Q} / \sqrt{\mathrm{g} \times \mathrm{D}^{5}}\right)$ and $\left(\mathrm{E}_{1} / \mathrm{D}\right)$ for different values of Submerged ratios of $\left(H_{d} / D\right),\left(\theta_{1}=15\right)$. that,

From the previous figures it can be investigate

1- The increase of the pipe Froude number leads to an increase in the relative upstream energy at a specific value of submergence ratio.

2- The upstream energy increases for the increase of the submergence ratio at the same value of pipe Froude number. The previous results are conducted also for other inlet cutting angles $\left(\theta_{1}=30^{\circ}, 45^{\circ}\right.$, and $\left.60^{\circ}\right)$. Figs. (4), (5) describes the relationships between pipe Froude number and relative upstream energy $\left(E_{1} / D\right)$ for different values of inlet cutting angle $\left(\theta_{1}=0^{\circ}\right.$, $15^{\circ}, 30^{\circ}, 45^{\circ}$, and $60^{\circ}$ ), and for different values of submergence ratio $\left(\mathrm{H}_{\mathrm{d}} / \mathrm{D}=0.00,0.25\right)$ respectively. 


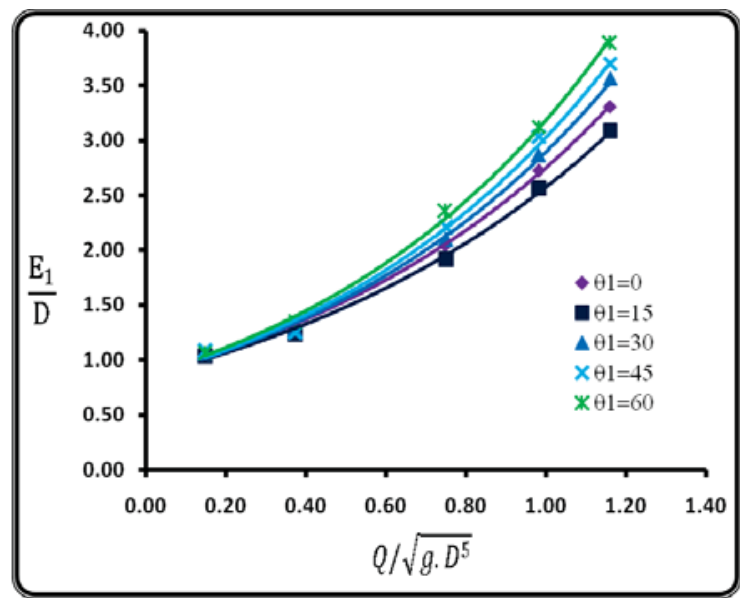

Fig. (4) Relationship between

$\left(\mathrm{Q} / \sqrt{\mathrm{g} \times \mathrm{D}^{5}}\right)$ and $\left(\mathrm{E}_{1} / \mathrm{D}\right)$ for different values of $\left(\theta_{1}\right)$, and Submerged ratios of $\left(\mathrm{H}_{\mathrm{d}} / \mathrm{D}=0\right)$.

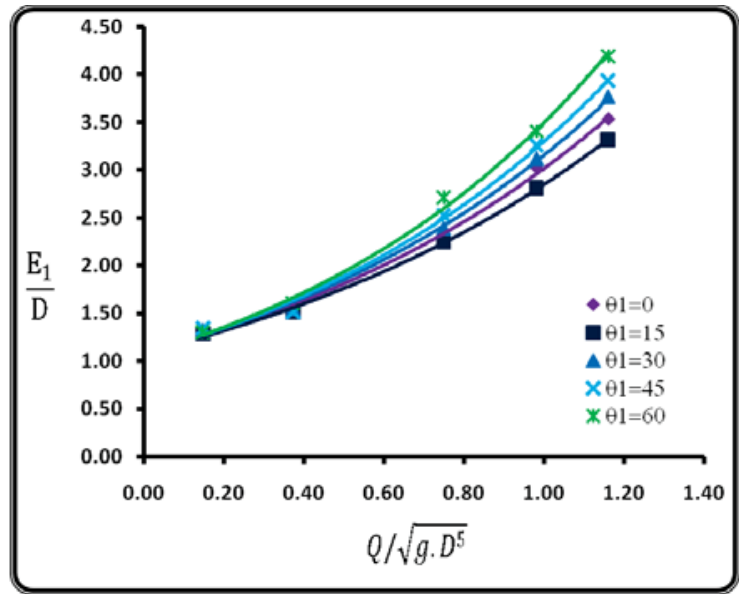

Fig. (5) Relationship between

$\left(\mathrm{Q} / \sqrt{\mathrm{g} \times \mathrm{D}^{5}}\right)$ and $\left(\mathrm{E}_{1} / \mathrm{D}\right)$ for different values of $\left(\theta_{1}\right)$, and submergence ratio of $\left(\mathrm{H}_{\mathrm{d}} / \mathrm{D}=0.25\right)$.

From the observation of the above figure it can be obtained that,

1- As the pipe Froude number increases, the relative upstream energy increases at a specified value of inlet cutting angles.

2- The upstream relative energy increases with the increase of the inlet cutting angle.

3 - The inlet cutting angle $\left(\theta_{1}=15^{\circ}\right)$ has a minimum relative energy at upstream side of the syphon.

4- Results of relative submerged depths $\left(\mathrm{H}_{d} / \mathrm{D}\right.$ $=0.50,0.75,1.00$ ) give the same behavior.

From all previous curves the relative energy at upstream side of the syphon results mainly from the increase of potential energy, which indicated by the increase of upstream water depth. This results can be confirmed by Figs. (6) and (7)which describe the relationship between pipe Froude number $\left(\mathrm{Q} / \sqrt{\mathrm{g} \times \mathrm{D}^{5}}\right)$, and relative submerged depth at the upstream side of the syphon $\left(\mathrm{H}_{\mathrm{u}} / \mathrm{D}\right)$, for different values of relative submerged depth at the downstream side of the syphon $\left(\mathrm{H}_{\mathrm{d}} / \mathrm{D}\right)$, and inlet cutting angles $\quad\left(\theta_{1}=\quad 0^{\circ}, 15^{\circ}, 30^{\circ}, 45^{\circ}\right.$, an $\left.60^{\circ}\right)$ respectively.

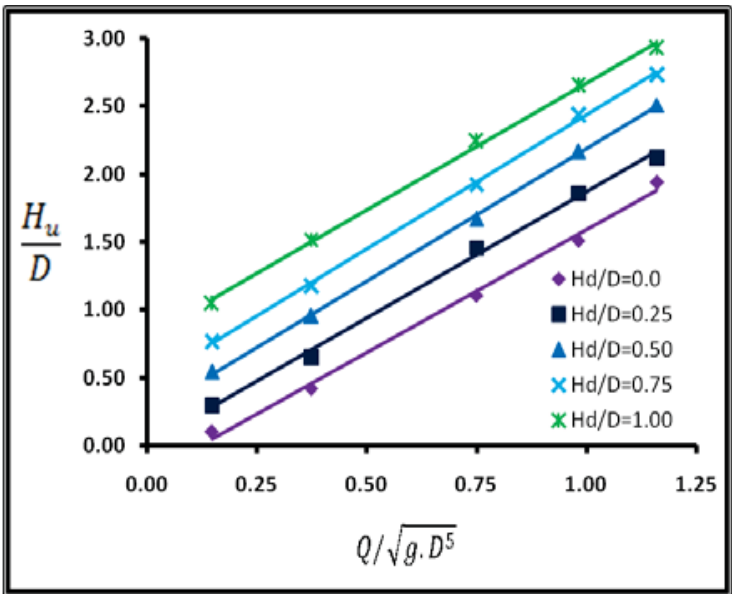

Fig. (6) Relationship between

$\left(\mathrm{Q} / \sqrt{\mathrm{g} \times \mathrm{D}^{5}}\right)$ and $\left(\mathrm{H}_{\mathrm{u}} / \mathrm{D}\right)$ for different values of Submerged ratios $\left(\mathrm{H}_{\mathrm{d}} / \mathrm{D}\right)$, and $\left(\theta_{1}=0\right)$.

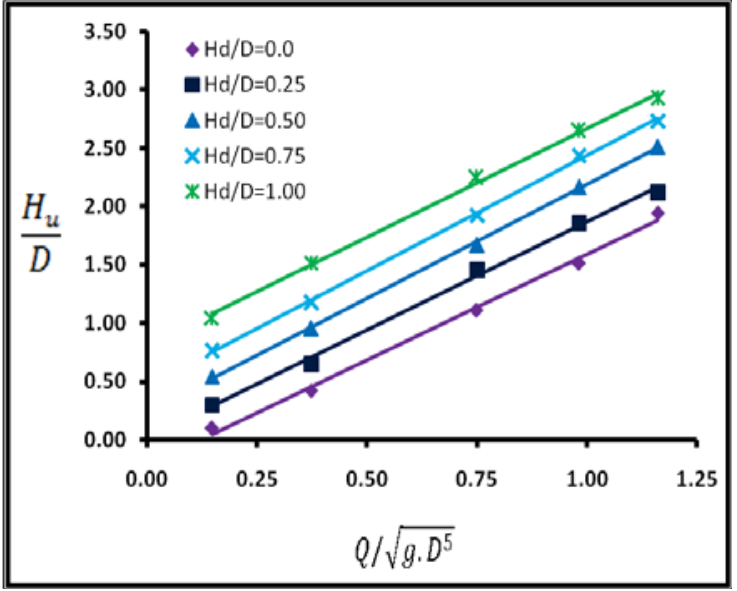

Fig. (7) Relationship between

$\left(\mathrm{Q} / \sqrt{\mathrm{g} \times \mathrm{D}^{5}}\right)$ and $\left(\mathrm{H}_{\mathrm{u}} / \mathrm{D}\right)$ for different values of Submerged ratios $\left(H_{d} / D\right)$, and $\left(\theta_{1}=15\right)$.

From the previous curves it can be mentioned also that the relative submerged depth upstream side of syphon increases with the increase of pipe Froude number at a specific relative submerged depth downstream syphon. And the increase of the relative submerged depth associated with increasing relative submerged depth in downstream. 
Analyzing and comparing results from the previous curved with changing inlet cutting angles of the pipe at a constant value of submerged depth conspicuous the inlet cutting angle of 15 degree with vertical axis is the best cutting angle as mentioned in the following curves (8), (9), (10), (11), and (12).

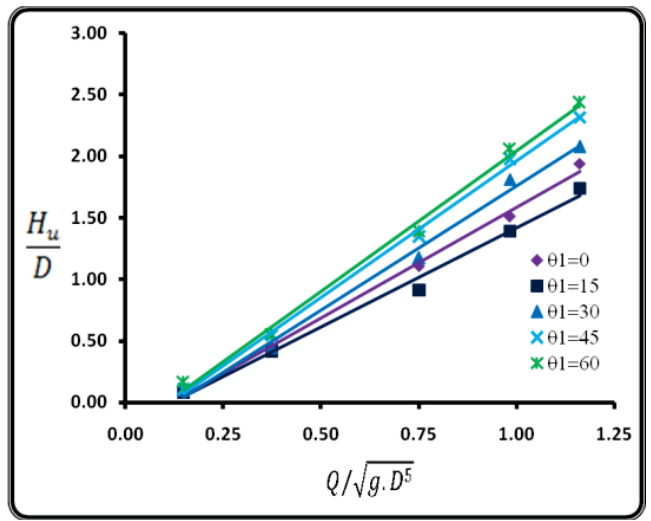

Fig. (8 Relationship between

$\left(\mathrm{Q} / \sqrt{\mathrm{g} \times \mathrm{D}^{5}}\right)$ and $\left(\mathrm{H}_{\mathrm{u}} / \mathrm{D}\right)$ for different values of $\left(\theta_{1}\right)$, and Submerged ratios of $\left(\mathrm{H}_{\mathrm{d}} / \mathrm{D}=0.0\right)$.

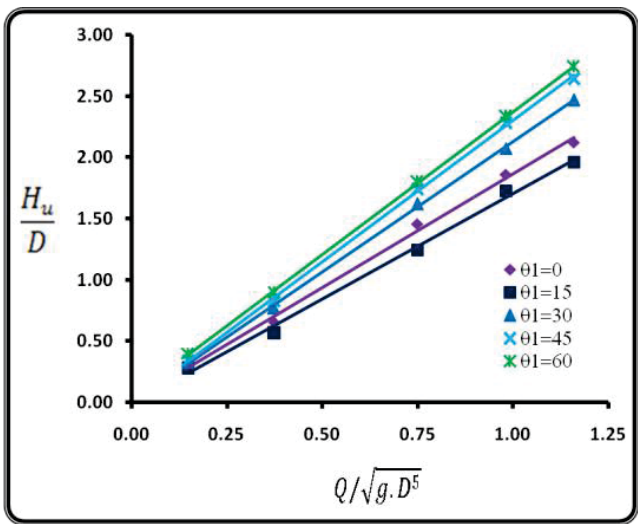

Fig. (9) Relationship between

$\left(\mathrm{Q} / \sqrt{\mathrm{g} \times \mathrm{D}^{5}}\right)$ and $\left(\mathrm{H}_{\mathrm{u}} / \mathrm{D}\right)$ for different values of $\left(\theta_{1}\right)$, and Submerged ratios of $\left(\mathrm{H}_{\mathrm{d}} / \mathrm{D}=0.25\right)$.

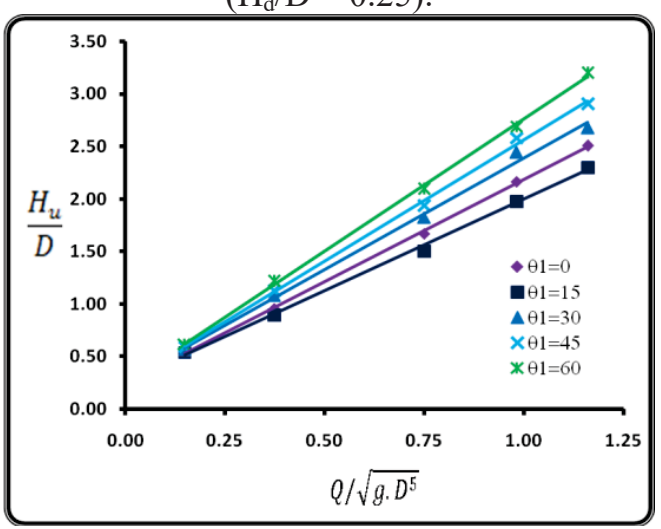

Fig. (10) Relationship between

$\left(\mathrm{Q} / \sqrt{\mathrm{g} \times \mathrm{D}^{5}}\right)$ and $\left(\mathrm{H}_{\mathrm{u}} / \mathrm{D}\right)$ for different values of $\left(\theta_{1}\right)$, and Submerged ratios of $\left(\mathrm{H}_{\mathrm{d}} / \mathrm{D}=\right.$ $0.50)$.

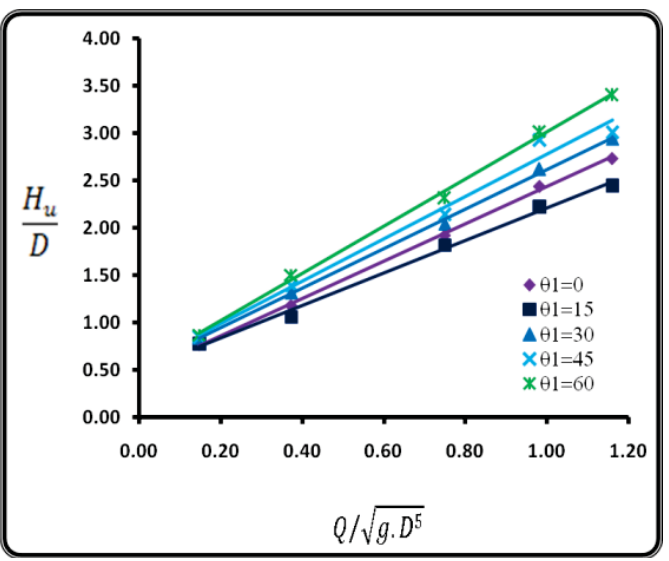

Fig. (11) Relationship between $\left(\mathrm{Q} / \sqrt{\mathrm{g} \times \mathrm{D}^{5}}\right)$ and $\left(\mathrm{H}_{\mathrm{u}} / \mathrm{D}\right)$ for different values of $\left(\theta_{1}\right)$, and Submerged ratios of $\left(\mathrm{H}_{\mathrm{d}} / \mathrm{D}=0.75\right)$.



Fig. (12) Relationship between $\left(\mathrm{Q} / \sqrt{\mathrm{g} \times \mathrm{D}^{5}}\right)$ and $\left(\mathrm{H}_{\mathrm{u}} / \mathrm{D}\right)$ for different values of $\left(\theta_{1}\right)$, and Submerged ratios of $\left(\mathrm{H}_{\mathrm{d}} / \mathrm{D}=1.0\right)$.

By analyzing the experimental data, it is observed that the relative total head loss increases with the increase of pipe Froude number for all inlets cutting angles, as indicated in Figs. (13) and (14) 




Fig. (13) Relationship between

$\left(\mathrm{Q} / \sqrt{\mathrm{g} \times \mathrm{D}^{5}}\right)$ and $\left(\mathrm{E}_{\mathrm{t}} / \mathrm{D}\right)$ for different values of Submerged ratios of $\left(H_{d} / D\right),\left(\theta_{1}=0\right)$.

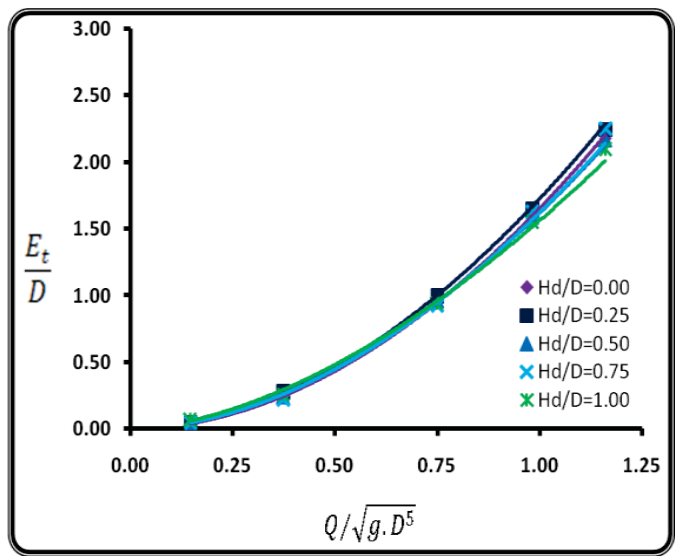

Fig. (14) Relationship between

$\left(\mathrm{Q} / \sqrt{\mathrm{g} \times \mathrm{D}^{5}}\right)$ and $\left(\mathrm{E}_{\mathrm{t}} / \mathrm{D}\right)$ for different values of Submerged ratios of $\left(\mathrm{H}_{\mathrm{d}} / \mathrm{D}\right),\left(\theta_{1}=15\right)$.

The same attitude and results is established for other inlet cutting angles $\left(\theta_{1}=30,45\right.$, and $60)$. By collecting and analyzing data at the same relative submerged depth upstream side of syphon. It is obvious that the inlet cutting angle $\left(\theta_{1}=15\right)$ gives minimum relative total losses through syphon for all relative submerged depths, as shown in Figs. (15) and (16).

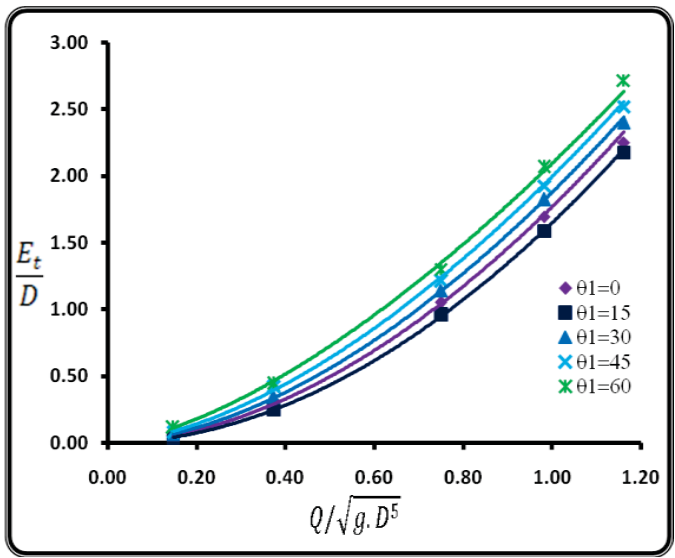

Fig. (15) Relationship between

$\left(\mathrm{Q} / \sqrt{\mathrm{g} \times \mathrm{D}^{5}}\right)$ and $\left(\mathrm{E}_{\mathrm{t}} / \mathrm{D}\right)$ for different values of $\left(\theta_{1}\right)$, and Submerged ratios of $\left(\mathrm{H}_{\mathrm{d}} / \mathrm{D}=0.0\right)$.

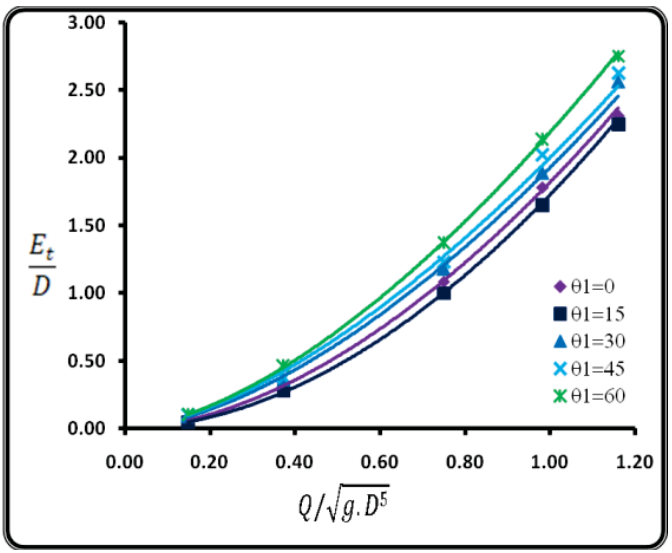

Fig. (16) Relationship between $\left(\mathrm{Q} / \sqrt{\mathrm{g} \times \mathrm{D}^{5}}\right)$ and $\left(\mathrm{E}_{\mathrm{t}} / \mathrm{D}\right)$ for different values of $\left(\theta_{1}\right)$, and Submerged ratios of $\left(\mathrm{H}_{\mathrm{d}} / \mathrm{D}=0.25\right)$.

Finally analyzing the experimental data for relative entrance losses and compare the results of different inlet cutting angles, the minimum relative entrance losses was conducted from $\left(\theta_{1}=15\right)$ as shown in Figs. from (17) to (21). 




Fig. (17) Relationship between $\left(\mathrm{Q} / \sqrt{\mathrm{g} \times \mathrm{D}^{5}}\right)$ and $\left(\mathrm{H}_{\mathrm{ent}} / \mathrm{D}\right)$ for different values of

$\left(\theta_{1}\right)$, and Submerged ratios of $\left(\mathrm{H}_{\mathrm{d}} / \mathrm{D}=0.0\right)$.

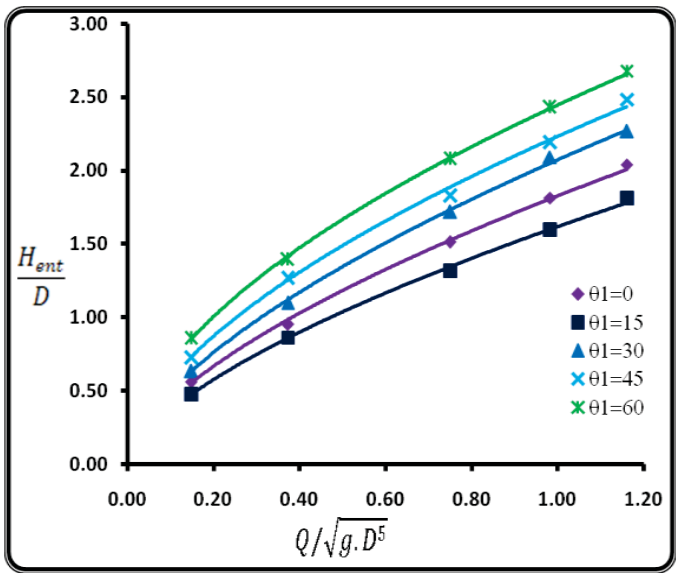

Fig. (18) Relationship between

$\left(\mathrm{Q} / \sqrt{\mathrm{g} \times \mathrm{D}^{5}}\right)$ and $\left(\mathrm{H}_{\mathrm{ent}} / \mathrm{D}\right)$ for different values of

$\left(\theta_{1}\right)$, and Submerged ratios of $\left(\mathrm{H}_{\mathrm{d}} / \mathrm{D}=0.25\right)$.

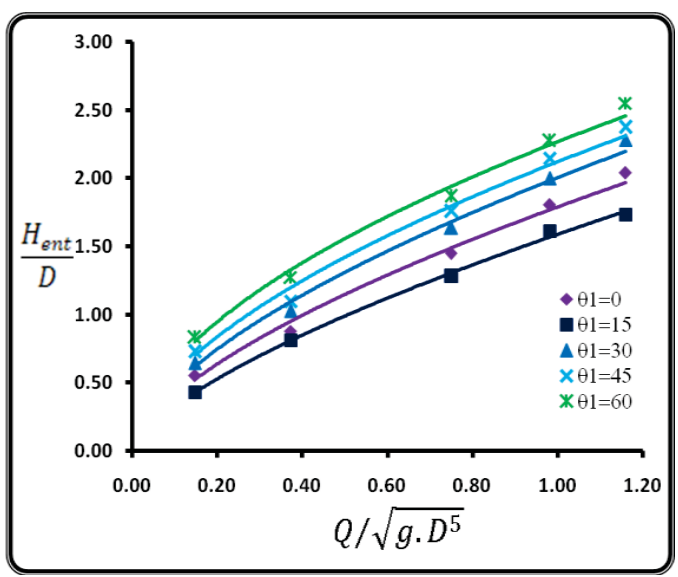

Fig. (19) Relationship between

$\left(\mathrm{Q} / \sqrt{\mathrm{g} \times \mathrm{D}^{5}}\right)$ and $\left(\mathrm{H}_{\mathrm{ent}} / \mathrm{D}\right)$ for different values of $\left(\theta_{1}\right)$, and Submergence ratios of $\left(H_{d} / D=0.50\right)$.

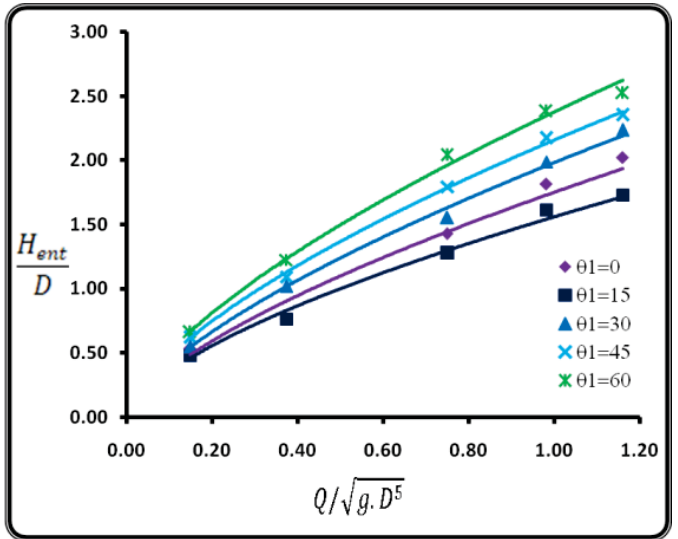

Fig. (20) Relationship between

$\left(\mathrm{Q} / \sqrt{\mathrm{g} \times \mathrm{D}^{5}}\right)$ and $\left(\mathrm{H}_{\mathrm{ent}} / \mathrm{D}\right)$ for different values of

$\left(\theta_{1}\right)$, and Submerged ratios of $\left(\mathrm{H}_{\mathrm{d}} / \mathrm{D}=0.75\right)$.

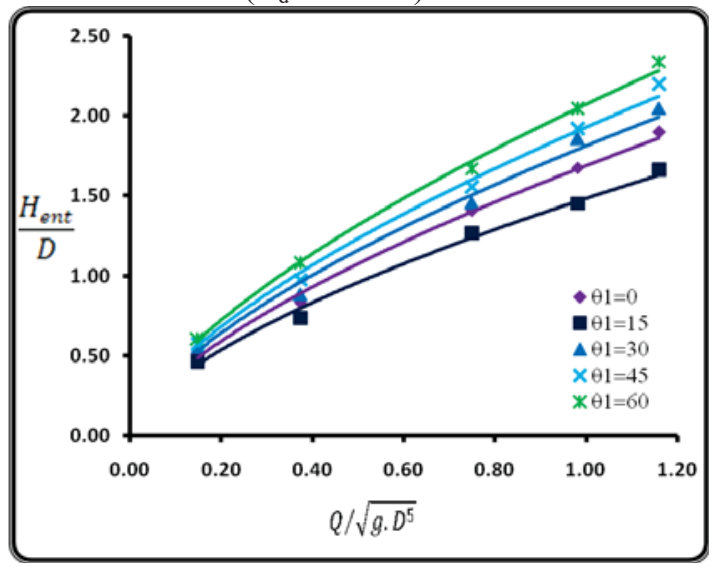

Fig. (21) Relationship between

$\left(\mathrm{Q} / \sqrt{\mathrm{g} \times \mathrm{D}^{5}}\right)$ and $\left(\mathrm{H}_{\mathrm{ent}} / \mathrm{D}\right)$ for different values of

$\left(\theta_{1}\right)$, and Submerged ratios of

$\left(\mathrm{H}_{\mathrm{d}} / \mathrm{D}=1.00\right)$.

\section{STATISTICAL MODEL:}

A statistical model was conducted by using $\mathrm{E}_{\mathrm{t}} / \mathrm{D}$ as dependant parameter and $\theta_{1}, \mathrm{E}_{1} / \mathrm{D}, \mathrm{E}_{4} / \mathrm{D}, \mathrm{H}_{\mathrm{ent}} / \mathrm{D}, \mathrm{H}_{\mathrm{d}} / \mathrm{D}$, and $\mathrm{Q}$ $/ \sqrt{\mathrm{g} \times \mathrm{D}^{5}}$ as independent parameters. Non linear regression analysis technique was used to get an equation connecting between variables as stated in equation (2)

$$
\begin{aligned}
& \frac{E_{t}}{D}=0.001 \theta_{1}+0.81 \frac{E_{1}}{D}-0.943 \frac{E_{4}}{D}+0.046 \frac{H_{e n t}}{D} \\
& -0.173 \frac{H_{d}}{D}+0.277 \frac{H_{u}}{D}+0.674 \frac{Q}{\sqrt{D^{5} \cdot g}} \ldots
\end{aligned}
$$


The statistical results represented in predicted $E_{t} / D$ was compared with $E_{t} / D$ calculated from the experimental results as shown in Fig. (22). The homogeneity of data around 45 inclined degree comparative line was observed with $\mathrm{R}^{2}=0.995$. Standard deviation of the data was found around $6 \%$. So, the equation results from statistical analysis model are a reliable equation in calculating relative head loss resulting from the syphon.

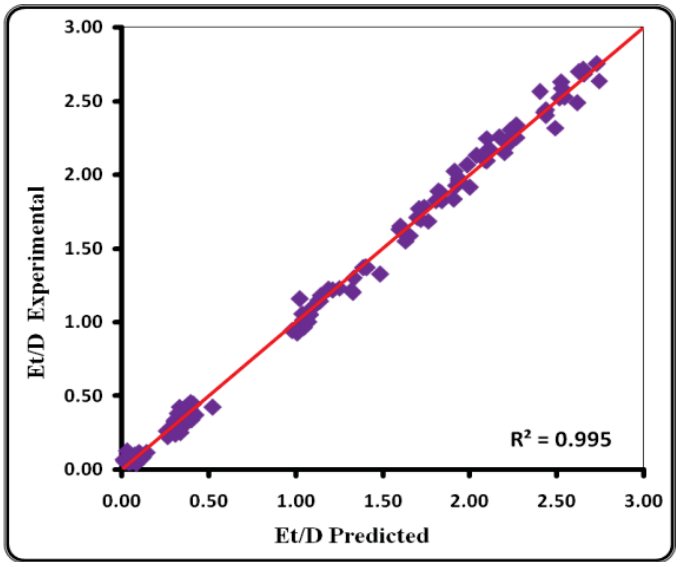

Fig. (22) Relationship between $E_{t} / D$ predicted and $E_{t} / D$ experimental

\section{CONCLUSIONS:}

From the theoretical and experimental studies, that is conducted on a pipe syphon in order to reduce the losses resulting from passing discharges, and by analysis and comparing the results. The study concluded the following,

1- The increasing of relative upstream energy $\left(E_{1} / D\right)$ results mainly from the increasing of water depth not the increasing of velocity head.

2- The relative total head losses through the syphon increases with the increase of pipe Froude number for different values of submergence ratios for all inlet cutting angles.

3- The inlet cutting angle of $\left(\theta_{1}=15^{\circ}\right)$ gives the minimum relative total losses and minimum relative entrance losses.

4- The comparison between experimental measurement of $E_{t} / D$ and the predicted results from the statistical equation for the same variable $\mathrm{E}_{\mathrm{t}} / \mathrm{D}$ indicate an acceptable agreement with $\mathrm{R}^{2}=0.995$.

\section{Nomenclature}

$\theta_{1}$ :Cutting angle of pipe inlet at the upstream side of the syphon,

$\mathbf{B}_{1}$ : Width of the canal,

$\mathbf{B}_{2}$ :Distance between wing walls,

D: Diameter of the pipe syphon,

$\mathbf{E}_{1}$ : Total energy upstream of the syphon,

$\mathbf{E}_{2}$ : Total energy behind the inlet of the syphon,

$\mathbf{E}_{2}$ : Total energy behind the inlet head wall of the syphon,

$\mathbf{E}_{3}{ }_{3}$ : Total energy at the end of the syphon before outlet,

$\mathbf{E}_{3}$ : Total energy at the end of the syphon between outlet wing walls,

$\mathbf{E}_{4}$ :Total energy downstream of the syphon,

$\mathbf{E}_{\mathbf{t}}$ : Total head loss through the syphon,

$\mathbf{H}_{\mathrm{d}}$ : Water depth above pipe outlet,

$\mathbf{H}_{\text {ent }}$ : Entrance losses at the inlet of syphon,

$\mathbf{H}_{\mathrm{u}}$ : Water depth above pipe inlet,

L: Pipe length,

Q: Passing discharge,

$\mathbf{y}_{1}$ : Upstream water depth before the inlet of the syphon,

$\mathbf{y}_{2}$ : Upstream water depth between the inlet wing walls of the syphon,

$\mathbf{y}_{3}$ : Downstream water depth between the outlet wing walls,

$\mathbf{y}_{4}$ : Downstream water depth behind of the outlet wing walls,

$\left(\mathrm{Q} / \sqrt{\mathrm{g} \times \mathrm{D}^{5}}\right):$ Pipe Froude number

\section{REFERENCES}

[1] Blaisdell, F. W. (1960). "Hood Inlet for Closed Conduit Spillways", Journal of Hydraulic Division, ASCE, Vol. 86, No.5, PP. 7-31.

[2] Bodhaine, G. L. (1982). "Measurement of Peak Discharge at Culvert by Indirect Method", Section A3, Book 3. U.S., Geological Survey, Government Printing Office, Washington D.C.

[3] Buckingham, E. (1914). "On Physically Similar System: Illustration of the Used Dimensional Analysis", Phys. Rev. 4, PP.345376.

[4] Chow, V. T., (1959). "Open Channel Hydraulics ", McGraw-Hill, book company, Chapter 17, PP. 493-498. 
[5]Dasika, B. (1995). "New Approach to Design of Culvert", Journal of Irrigation and Drainage Engineering, ASCE, Vol. 121, No.3, PP. 261-264.

[6] David A. C., (2013). "Hydraulic Analysis and Design of Pipe Culverts: USGS vs. FHWA", ASCE, Journal of Hydraulic Engineering, Vol. 139, No.5, PP. 271-274.

[7] Magdy H. Mowafy, (1999). "Effect of Culvert Inlet Shape on Flow Discharge and Scour", ASCE, International Symposium on Environmental Hydrology, PP. 571-579.

[8] Metzler, D. E., and Rouse, H. (1959). "Hydraulics of Box Culverts ", Studies in Engineering Bullentin 38, Iowa State University, Ames, Iowa.

[9] Meselhe, E. and Hebert, K. (2007). "Laboratory Measurements of Flow through Culverts", Journal of Hydraulic Engineering 133, No.(8), PP.973-976.

[10] Montes, J. S. (1997). "Discussion of New Approach to Design of Culverts", Journal of Irrigation and Drainage Engineering, ASCE, Vol. 123, No.1, PP. 71-72.

[11] Robinson, S.C. (2005). "Hydraulic Characteristics of a Buried Inverted Elliptical Culvert Inlet and Quantification of Culvert Exit Loss", MS Thesis, Utah State University, Logan, Utah.

[12] Smith C. D., and Oak, A. G. (1995). "Culvert Inlet Efficiency", Journal of Canadian Engineering, Vol. 22, PP. 611-616.

[13] Tullis B. and S. Robinson (2008). "Entrance Loss Coefficient and Inlet Control", Journal of Irrigation and Drainage

Engineering, ASCE, Vol. 134, No.6, PP. 831-839.

[14] U.S. Department of Transportation, Federal Highway Administration. (2012a)." Hydraulic design of highway culverts", Third edition, Hydraulic Design Series Number 5 (HDS5) No. FHWA-HIF-12-026. Washington, DC.

[15] U.S. Department of Transportation, Federal Highway Administration (2012b). "Culvert hydraulics-Software, HY-8 FHWA culvert analysis", version 7.3.

[16] Willi H. Hager, Giuseppe Del Giudice (1998). "Generalized Culvert Design Diagram “,
Journal of Irrigation and Drainage Engineering, Vol.124, No.5, PP. 271-274. 